\title{
Characterization of DNA polymerase $\beta$ from Danio rerio by overexpression in $E$. coli using the in vivo/in vitro compatible pIVEX plasmid
}

Tomomi Ishido ${ }^{1}$, Naoshi Yamazaki ${ }^{2}$, Mitsuru Ishikawa ${ }^{1}$ and Ken Hirano ${ }^{1 *}$

\begin{abstract}
Background: Eukaryotic DNA polymerase $\beta$ ( $\mathrm{pol} \beta$ ), the polymerase thought to be responsible for DNA repair synthesis, has been extensively characterized in rats and humans. However, pol $\beta$ has not been purified or enzymatically characterized from the model fish species Danio rerio (zebrafish). We used the in vitro/in vivo dual expression system plasmid, pIVEX, to express Danio rerio pol $\beta$ (Danio pol $\beta$ ) for biochemical characterization.

Results: Danio pol $\beta$ encoded by the in vitro/in vivo-compatible pIVEX plasmid was expressed in E. coli BL21(DE3), BL21(DE3)pLysS, and KRX, and in vitro as a C-terminal His-tagged protein. Danio pol $\beta$ expressed in vitro was subject to proteolysis; therefore, bacterial overexpression was used to produce the protein for kinetic analyses. KRX cells were preferred because of their reduced propensity for leaky expression of pol $\beta$. The cDNA of Danio rerio pol $\beta$ encodes a protein of 337 amino acids, which is $2-3$ amino acids longer than other pol $\beta$ proteins, and contains a P63D amino acid substitution, unlike mammalian pol $\beta$ s. This substitution lies in a hairpin sequence within an 8$\mathrm{kDa}$ domain, likely to be important in DNA binding. We performed extensive biochemical characterization of Danio pol $\beta$ in comparison with rat pol $\beta$, which revealed its sensitivity to metal ion activators $\left(\mathrm{Mn}^{2+}\right.$ and $\left.\mathrm{Mg}^{2+}\right)$, its optimum salt concentration (10 mM KCl and $50 \mathrm{mM} \mathrm{NaCl}$ ), alkaline pH optimum (pH 9.0), and low temperature optimum $\left(30^{\circ} \mathrm{C}\right)$. Substituting $\mathrm{Mn}^{2+}$ for $\mathrm{Mg}^{2+}$ resulted in 8.6-fold higher catalytic efficiency $\left(k_{\text {cat }} / K_{\mathrm{m}}\right)$.

Conclusions: Our characterization of pol $\beta$ from a model fish organism contributes to the study of the function and evolution of DNA polymerases, which are emerging as important cellular targets for chemical intervention in the development of anticancer agents.
\end{abstract}

\section{Background}

In eukaryotic cells, nuclear DNA replication and repair relies on five species of DNA polymerases (pols): $\alpha, \beta, \gamma$, $\delta$ and $\varepsilon$ [1-3]. Additional DNA pols have been discovered, namely, pol $\lambda, \mu, \zeta, \eta, \theta, \iota, \kappa, \sigma$ and REV1 [4,5]. These pols have emerged as important cellular targets for chemical intervention in the development of anticancer agents $[6,7]$. Of these pols, pol $\beta$ is thought be involved in DNA repair synthesis [8]. This enzyme belongs to family $\mathrm{X}$, which includes pol $\lambda$, $\mu$, and terminal deoxynucleotidyltransferase (TdT). Pol $\beta$ is the smallest polymerase in family $\mathrm{X}$. Other members of the family have a nuclear localization signal (NLS), a

\footnotetext{
* Correspondence: hirano-ken@aist.go.jp

${ }^{1}$ Health Research Institute, National Institute of Advanced Industrial Science and Technology (AIST), Takamatsu, Kagawa 761-0395, Japan

Full list of author information is available at the end of the article
}

BRCA1 C-terminal (BRCT) domain, and a proline rich region. Mammalian pol $\beta$ is a single polypeptide of 39 $\mathrm{kDa}$, comprising 335 amino acids forming two domains: an $8 \mathrm{kDa} \mathrm{N}$-terminal domain and a $31 \mathrm{kDa}$-terminal domain, connected with a protease-hypersensitive hinge region. The former domain possesses a template-binding function and a dRPase activity to remove the 5'-deoxyribose phosphate, the latter domain possesses DNA polymerase activity. Biochemical studies have shown that pol $\beta$ releases the 5'-terminal dRP residues from the aprinic/ apyrimidinic sites and fills short gaps of one to six nucleotides. These activities indicate that pol $\beta$ functions in base excision repair (BER), which is a major pathway for repairing modified bases in DNA [9].

Both rat and human pol $\beta$ genes have been cloned, the crystal structures were determined, and an active recombinant enzyme has been overexpressed in Escherichia 
coli [10]. However, only a few papers on the properties of pol $\beta$ from lower vertebrates, particularly from the fish kingdom, such as Oncorhynchus masou (cherry salmon) [11] and Xiphophorus maculaus [12], have been reported.

Danio rerio (zebrafish) has long been used as a model organism in the fields of molecular genetics and developmental biology of vertebrates [13]. D. rerio constitutes a powerful animal model, largely because of their small size, optical clarity, fecundity, rapid development, and large arsenal of readily available genetic tools [14]. The D. rerio model system is amenable to whole-genome forward genetic approaches, which facilitates experimental manipulation and allows the direct observation of tissue formation and organogenesis in vivo [15]. Thus, research using $D$. rerio has allowed advances in fields such as developmental biology, oncology, toxicology, and regenerative medicine [16-18]. However, the purification and enzymatic characterization of pol $\beta$ from $D$. rerio has not been reported.

The pIVEX plasmid, which is optimized in the Rapid Translation System (RTS) as cell-free protein expression system, is a useful compatible vector for both in vivo and in vitro expression systems based on $E$. coli, pIVEX permits comparison between cell-free and bacterial expression from the same genetic construct [19]. The pIVEX vector system is particularly useful for (i) bacterial expression after cell-free expression for scale-up of protein expression and solution of problems such as poor protein yields or expression results, and (ii) cell-free expression when the recombinant protein cannot be expressed in bacteria cells. In fact, in the present study, we found
pIVEX carrying the Danio rerio pol $\beta$ (Danio pol $\beta$ ) cDNA causes growth inhibition of BL21(DE3)pLysS cells before expression induction, which contrasted with other proteins that were reported to be expressed in the PIVEX vector system using BL21(DE3)pLysS cells $[19,20]$. Thus, the determination of the correct plasmid/host combination is required for the expression certain proteins.

In the present study, we report the overproduction and enzymatic characterization of Danio pol $\beta$ using the pIVEX plasmid in E. coli. We revealed that Danio pol $\beta$ was overproduced in the E. coli expression host by substituting ordinary BL21(DE3) cells with KRX cells. The enzymatic properties of the purified recombinant Danio pol $\beta$ were examined and compared with rat pol $\beta$. The Michaelis constants, $K_{\mathrm{m}}$ and $k_{\text {cat }}$, and the catalytic efficiencies $\left(k_{\mathrm{cat}} / K_{\mathrm{m}}\right)$ for recombinant Danio pol $\beta$ were also determined by pol $\beta$-mediated nucleotide incorporation during primer extension.

\section{Results and Discussion}

Comparison of amino acids sequences among various pol $\beta$ s Figure 1 shows a comparison of pol $\beta$ amino acid sequences from $D$. rerio, frog, rat, and human. The cDNA of $D$. rerio pol $\beta$ encodes a protein of 337 amino acids, which is two residues longer than the human, rat, calf, or mouse protein (all 335 amino acids) and three residues longer than that of frog (334 amino acids). The polypeptide length of Danio pol $\beta$ was the same as for pol $\beta$ in another fish, Xiphophorus maculaus. The amino acid sequence of Danio rerio pol $\beta$ has $80 \%$ sequence identity to the equivalent sequence in rats, 
$79 \%$ to the human protein, and $82 \%$ to the frog protein. One notable amino acid difference between the $D$. rerio and the mammalian proteins was the P63D amino acid substitution in $D$. rerio. This difference occurs in the L62-P63-G64-V65-G66 sequence in human and rat pol $\beta$, which represents a hairpin sequence within the $8-\mathrm{kDa}$ domain. This region exhibits a high degree of polypeptide backbone motion, which is likely to be important in DNA binding as well as in the formation of the dNTP binding pocket [11]. Other key residues are: D190, D192 and D256 for base pair geometry in active site, and control of binding and placement of catalytic metal ion; Y267 for stabilizing the nucleotide binding pocket and promoting proper alignment of primers, $\mathrm{Mg}^{2+}$, dNTP, and other active site residues; and R285 and K282 for hydrogen bonding of nascent base pairs to template nucleotides [12,21]. However, no differences in these other key residues were not observed in Danio pol $\beta$.

\section{Growth rate of $E$. coli cells transformed with pIVEX}

Danio pol $\beta$ was expressed as a C-terminal His-tagged fusion protein, using the pIVEX 2.3d expression system, in E. coli BL21(DE3), BL21(DE3)pLysS and KRX cells. After transformation into bacterial cells and picking the resultant colonies, bacterial cell growth was monitored by measuring the $\mathrm{OD}_{600}$ of the culture at $30 \mathrm{~min}$ intervals for $9 \mathrm{~h}$ without inducers (IPTG or rhamnose). Figure 2 shows that the growth of transformed BL21(DE3) and BL21(DE3)pLysS ceased at 3.5 and $4.0 \mathrm{~h}$, respectively; however, the growth of transformed KRX continued throughout the monitoring period, although growth

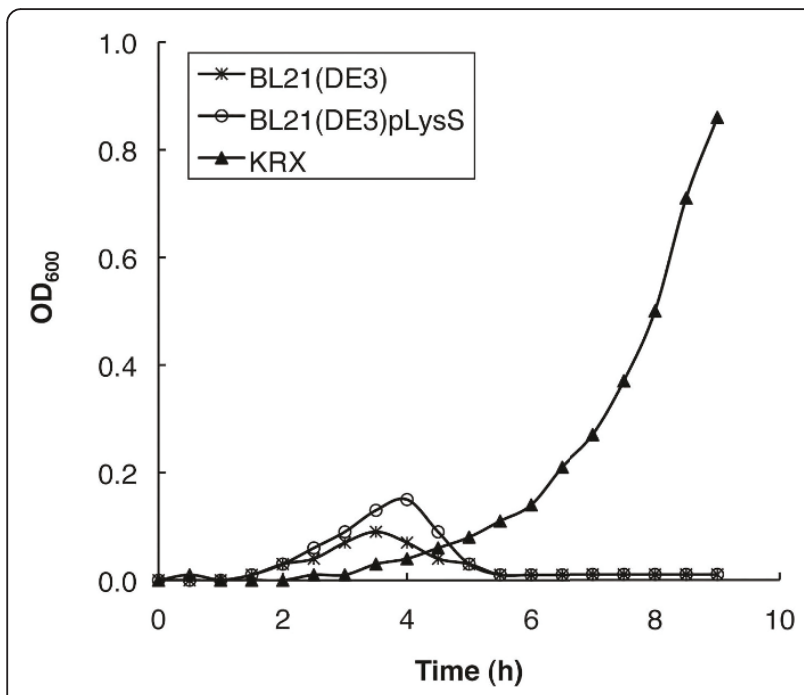

Figure 2 Growth curves of various $E$. coli cells harboring the pIVEX-Danio pol $\beta$ plasmid. The growth of transformed bacterial cells (BL21(DE3) (cross), BL21(DE3)pLysS (open circle) and KRX (open square)) was performed in $\mathrm{LB}$ medium at $30^{\circ} \mathrm{C}$. The $\mathrm{OD}_{600}$ was recorded at 30 min intervals. rate of KRX was slower than that of BL21(DE3) or BL21 (DE3)pLysS. We also tested cell growth with pIVEX-rat pol $\beta$ for comparison with pIVEX-Danio pol $\beta$. No inhibition of growth was observed using BL21(DE3)pLysS containing pIVEX-rat pol $\beta$ whereas the weak growth inhibition for transformed BL21(DE3) cells was observed as a growth delay (data not shown). Growth inhibition might be caused by the adverse effects of leaky expression of Danio pol $\beta$ in the bacterial cells. The lacI gene and its associated operator are not contained within pIVEX; therefore, when using pIVEX, transcription of the T7 RNA polymerase gene in the host chromosome at the lacUV5 promoter, and expression of recombinant protein at the T7 promoter are not controlled in BL21 (DE3). Suppression of the basal expression in BL21 (DE3)pLysS would also be difficult, because BL21(DE3) pLysS would not exert enough control of basal expression of T7 RNA polymerase, despite the T7 lysozyme encoded in the pLysS plasmid being an inhibitor of T7 RNA polymerase. The E. coli KRX cells, a derivative of the K12 strain, exerts precise control of T7 RNA polymerase gene transcription by the rhamnose promoter, permitting more exact control of recombinant protein expression. The basal protein production levels in KRX are 7 - and 20-fold lower than in BL21(DE3) and BL21 (DE3)pLysS, respectively [22]. Thus, we assume that precise suppression of basal expression of Danio pol $\beta$, which would be toxic to $E$. coli, is vital. For this reason, we selected pIVEX/KRX as the best plasmid/host combination to ensure stringent repression in the uninduced stationary state.

\section{Overexpression of Danio pol $\beta$}

To investigate the properties of Danio pol $\beta$, we expressed the recombinant protein using pIVEX-Danio pol $\beta$ in $E$. coli KRX. After induction with rhamnose, recombinant $C$-terminal His-tagged Danio pol $\beta$ was purified in a soluble form from the cell extracts by column chromatography with $\mathrm{Ni}^{2+}$-NTA resin. The production yield of the recombinant protein, based on the ratio of the amount of the purified protein against the volume of the culture medium, was $7.4 \mu \mathrm{g} / \mathrm{mL}$. The recombinant protein was analyzed by SDS-PAGE and Coomassie brilliant blue (CBB) staining. Figure 3A shows that His-tagged Danio pol $\beta$ protein was expressed from pIVEX-Danio pol $\beta$ in E. coli KRX. The recombinant His-tagged Danio pol $\beta$ protein was detected as a $39.8 \mathrm{kDa}$ band (Figure $3 \mathrm{~A}$ ).

To compare both in vivo and in vitro expression, we used the same pIVEX plasmid encoding Danio pol $\beta$. Figure $3 \mathrm{~B}$ shows that Danio pol $\beta$ was produced in a cell-free expression system using the pIVEX plasmid. From the western blotting analysis using anti-His ${ }_{6}$-antibody, proteolysis of Danio pol $\beta$ occurred during in 


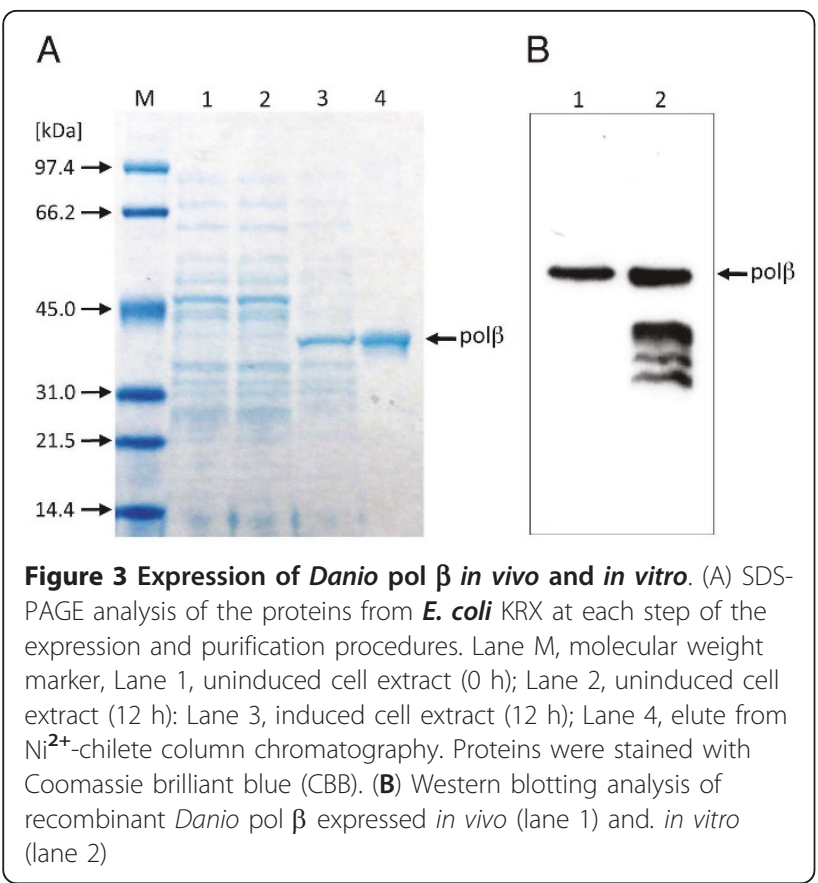

vitro expression (Figure 3B). As a result, bacterial expression was preferred to cell-free expression for Danio pol $\beta$.

\section{Enzymatic characterization of recombinant Danio rerio pol}

$\beta$

We investigated the effects of the metal ions $\mathrm{Mg}^{2+}$ and $\mathrm{Mn}^{2+}$ on Danio pol $\beta$ by measuring the enzyme activity in comparison with rat pol $\beta$. Figure $4 \mathrm{~A}$ shows that a sharp peak at $1 \mathrm{mM} \mathrm{Mg}^{2+}$ and a decrease in the activity was observed at concentrations higher than $10 \mathrm{mM} \mathrm{Mg}$ ${ }^{+}$for Danio pol $\beta$; in contrast, a peak at $5 \mathrm{mM} \mathrm{Mg}^{2+}$ with a broad decay was observed for rat pol $\beta$. Figure
$4 \mathrm{~B}$ shows that the optimal concentration of $\mathrm{Mn}^{2+}$ was $0.5 \mathrm{mM}$ for Danio pol $\beta$ and $1 \mathrm{mM}$ for rat pol $\beta$, followed by broadly reduced activity at higher concentrations. We also examined the effect of salt strength on pol $\beta$ activity, using increasing concentrations of $\mathrm{KCl}$ and $\mathrm{NaCl}$. Figure 5 shows that the concentrations permitting maximum activities of Danio pol $\beta$ and rat pol $\beta$ were the same for $\mathrm{KCl}$ and $\mathrm{NaCl}$, at $10 \mathrm{mM} \mathrm{KCl}$ and $50 \mathrm{mM} \mathrm{NaCl}$, respectively. No activity was observed at concentrations higher than $150 \mathrm{mM}$ for both $\mathrm{KCl}$ and $\mathrm{NaCl}$ for Danio pol $\beta$. The optimum conditions of metal ion and salt concentration for Danio pol $\beta$ were not significantly different compared with those for rat pol $\beta$. However, Figure $4 \mathrm{C}$ shows that Danio pol $\beta$ activity with $\mathrm{Mn}^{2+}$ was a dramatic 6.3-fold higher than that with $\mathrm{Mg}^{2+}$; in contrast, rat pol $\beta$ activity with $\mathrm{Mn}^{2+}$ was 3.1fold higher than that with $\mathrm{Mg}^{2+}$. Thus, $\mathrm{Mn}^{2+}$ is the optimal ion for pol $\beta$ enzyme activity. However, $\mathrm{Mn}^{2+}$ favors misincorporation of deoxynucleotides by pol $\beta$, compared with $\mathrm{Mg}^{2+}$. This agrees with the observation that $\mathrm{Mn}^{2+}$ is known to relax base-pairing specificity and to increase tolerance for substrates compared with $\mathrm{Mg}^{2+}$ for many polymerases [23]. For such reasons, $\mathrm{Mg}^{2+}$ was used as the metal ion in subsequent experiments.

We measured the $\mathrm{pH}$ dependence of Danio pol $\beta$ in the range between $\mathrm{pH} 7.0$ and $\mathrm{pH}$ 10.5. Figure 6Ashows peaks at pH 9.0 and 8.0 for Danio pol $\beta$ and rat pol $\beta$, respectively, although both enzymes showed activity in a rather broad $\mathrm{pH}$ range. The optimum $\mathrm{pH}$ in the alkaline range was similar to other eukaryotic pol $\beta$ enzymes. Danio pol $\beta$ lost activity at $\mathrm{pH} 10.5$.

We then examined the activity of Danio pol $\beta$ at various temperatures, from $15^{\circ} \mathrm{C}$ to $50^{\circ} \mathrm{C}$, and compared it with the rat polymerase activity. Figure $6 \mathrm{~B}$ shows that Danio pol $\beta$ was most active at $30^{\circ} \mathrm{C}$ and decreased by $50 \%$ at $35^{\circ} \mathrm{C}$ compared with the highest activity. Danio

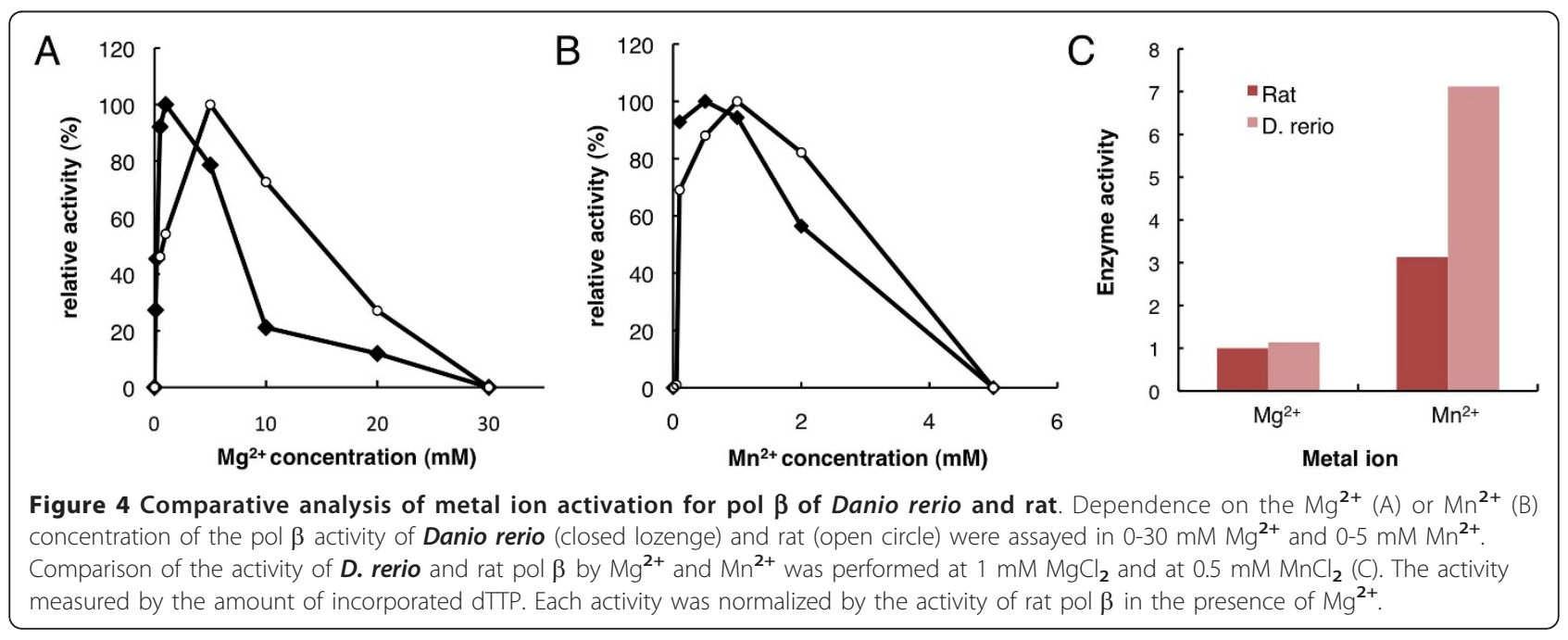




\section{B}
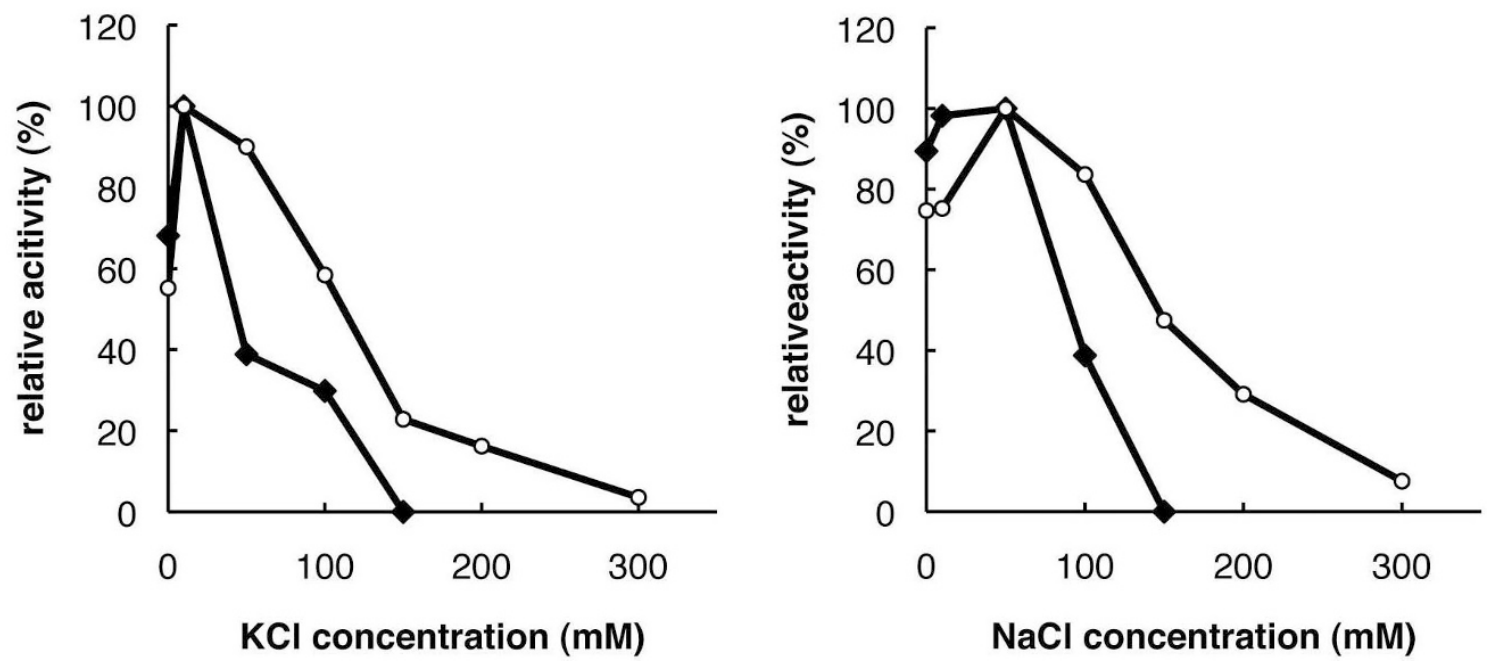

Figure 5 Effect of salt on Danio pol $\beta$. Effect of $\mathrm{KCl}(\mathrm{A})$ and $\mathrm{NaCl}(\mathrm{B})$ on the pol $\beta$ activities of Danio rerio (closed lozenge) and rat (open circle). The activities of pol $\beta$ were determined by the incorporation of dTTPs under standard assay conditions. Incubation was carried out at $30^{\circ}$ C (D. rerio) or $37^{\circ} \mathrm{C}$ (rat) for $5 \mathrm{~min}$.

pol $\beta$ was relatively sensitive to temperature compared with rat pol $\beta$. Furthermore, the optimum temperature of Danio pol $\beta$ was lower than that of rat pol $\beta\left(37^{\circ} \mathrm{C}\right)$. This observation corresponds to the lower temperature generally required by fish compared with the warmer body temperatures of humans and rats [11,12]. The fish and frog pol $\beta$ proteins contain the P63D variation compared with mammalian pol $\beta$ proteins. This difference might represent an important evolutionary mutation between cold-blooded and homeothermic organisms [12]. Indeed, Danio pol $\beta$ also has the P63D variation (Figure 1).

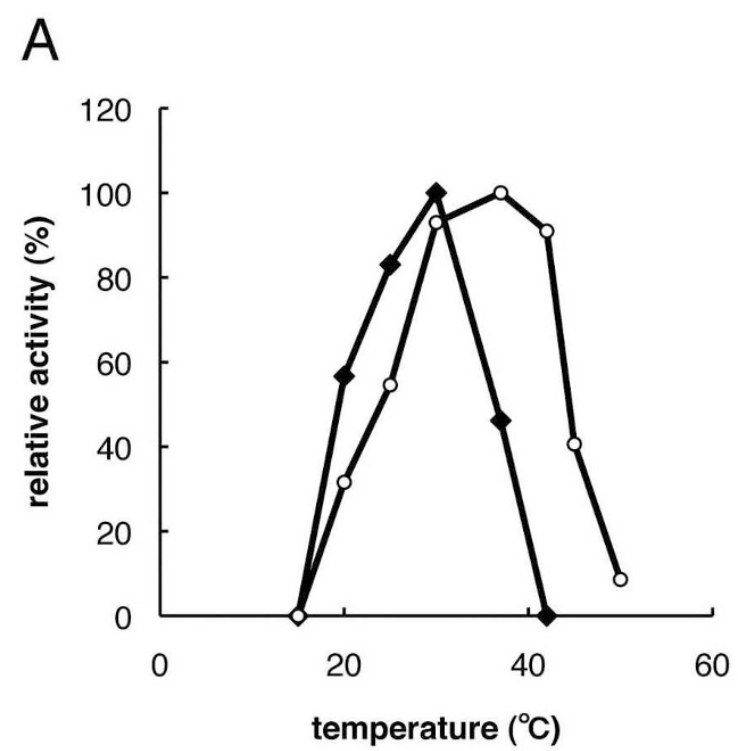

B

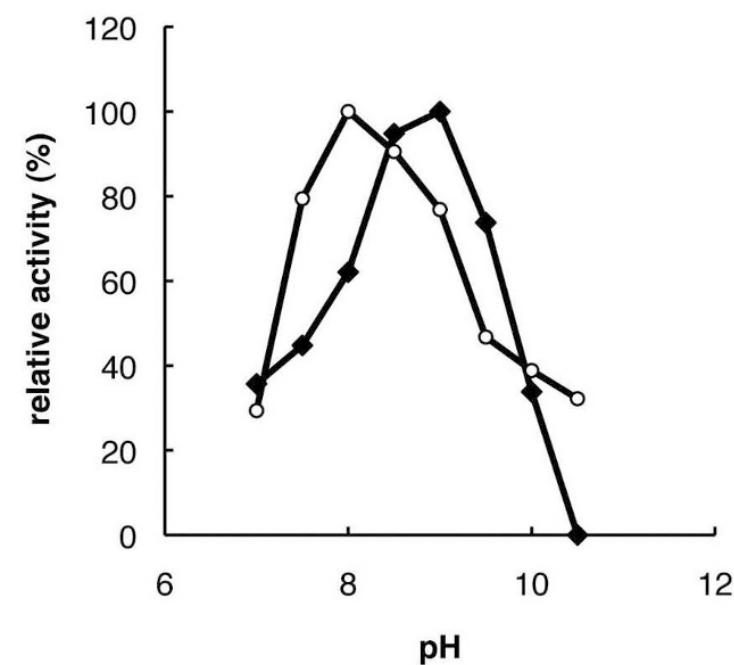

Figure 6 Apparent temperature and $\mathrm{pH}$ optima of Danio rerio pol $\beta$. Effect of temperature (A) and $\mathrm{pH}(\mathrm{B})$ on the pol $\beta$ activities of $\boldsymbol{D}$. rerio (closed lozenge) and rat (open circle). The activities of pol $\beta$ were determined by the incorporation dTTPs under standard assay conditions. (A) Effect of $\mathrm{pH}$ on pol $\beta$ activity was carried out at various pHs from 7.0-10.5. Incubation was carried out at $30^{\circ} \mathrm{C}$ (Danio rerio) or $37^{\circ} \mathrm{C}$ (rat) for 5 min. (B) Effect of temperature on pol $\beta$ activity was carried out at various temperatures: $15-42^{\circ} \mathrm{C}$ (Danio rerio) or $15-50^{\circ} \mathrm{C}$ (rat). 


\section{Kinetic assays of Danio pol $\beta$}

We investigated the kinetic constants $K_{\mathrm{m}}$ and $k_{\text {cat }}$, and the catalytic efficiency $k_{\text {cat }} / K_{\mathrm{m}}$ for Danio pol $\beta$ in the presence of either $\mathrm{Mg}^{2+}$ or $\mathrm{Mn}^{2+}$. Table 1 summarizes the calculated $K_{\mathrm{m}}, k_{\text {cat }}$, and $k_{\text {cat }} / K_{\mathrm{m}}$ of Danio pol $\beta$. Measurements for each dTTP concentration were performed with $\mathrm{Mg}^{2+}$ or $\mathrm{Mn}^{2+}$. From Hanes-Woolf plots, the kinetic parameters $K_{\mathrm{m}}$ and $k_{\text {cat }}$ for the analyzed substrate were derived, and their ratio $\left(k_{\mathrm{cat}} / K_{\mathrm{m}}\right)$ representing the efficiency of substrate utilization was calculated. As summarized in Table 1, in the presence of $\mathrm{Mn}^{2+}, K_{\mathrm{m}}$ decreased by 11.1 -fold compared with that with $\mathrm{Mg}^{2+}$, whereas the $k_{\text {cat }}$ values were similar, resulting in a significant increase $\left(8.6\right.$-fold) in $k_{\text {cat }} / K_{\mathrm{m}}$. The decrease in $K_{\mathrm{m}}$ represents an increased dNTP binding affinity. $\mathrm{Mn}^{2+}$ undergoes ligand exchange approximately 100 times faster than $\mathrm{Mg}^{2+}$, although $\mathrm{Mn}^{2+}$ serves as an excellent metal surrogate for $\mathrm{Mg}^{2+}$ because of its similar ionic radii and coordination geometries [24-26]. This relatively tight binding of $\mathrm{Mn}^{2+}$ to the dNTP binding site might increase in the activity. In contrast, a mechanism of nucleotide selectivity may depend on ligand exchange [27]. Thus, $\mathrm{Mn}^{2+}$ could act not only as an enhancer for catalytic efficiency but also as a potent mutagen [23]. The large difference in $k_{\text {cat }} / K_{\mathrm{m}}$ when substituting $\mathrm{Mn}^{2+}$ for $\mathrm{Mg}^{2+}$ may indicate that the fidelity of Danio pol $\beta$ is reduced.

\section{Conclusions}

We have succeeded in overproducing, purifying, and characterizing Danio pol $\beta$. Using a suitable plasmid/ host combination, Danio pol $\beta$ encoded by the in vitro/ in vivo compatible pIVEX plasmid was expressed in $E$. coli KRX. This combination was able to tightly suppress leaky expression of Danio pol $\beta$, which is a toxic protein for bacterial cell growth. The pIVEX/KRX combination required only one antibiotic, unlike previous work using two antibiotics because of the requirement for an extra plasmid, such as pLysS. This combination also forms an important tool for proteomics and structural biology, with its potential to express a variety of (growth toxic) recombinant proteins in both in vitro and in vivo. Furthermore, we performed extensive biochemical characterization of Danio pol $\beta$, which revealed its sensitivity to metal ion activators, its optimum salt concentration, alkaline $\mathrm{pH}$ optimum, and low temperature optimum. From the kinetic assays, we found that substituting $\mathrm{Mn}^{2}$ ${ }^{+}$for $\mathrm{Mg}^{2+}$ resulted in 8.6-fold higher catalytic efficiency $\left(k_{\text {cat }} / K_{\mathrm{m}}\right) \cdot \mathrm{Mn}^{2+}$ is considered a potential mutagen, and further experiments to investigate the sensitivity and fidelity with metal ion activators for Danio pol $\beta$ are underway. Moreover, we characterized pol $\beta$ from the $D$. rerio fish model. Pol $\beta$ is the smallest polymerase in eukaryotes, and it can be regarded as a basic model of various DNA polymerases. Our characterization of pol $\beta$ from a model fish organism contributes to the study of the function and evolution of DNA polymerases.

\section{Methods}

Construction of the pIVEX-Danio pol $\beta$ expression plasmid A 1019-bp cDNA sequence of Danio pol $\beta$ [DDBJ: AY648826] was artificially synthesized and codon-optimized for E. coli expression (Operon Biotechnologies). To clone the cDNA into pIVEX $2.3 \mathrm{~d}$ vector (5 Prime), which expresses the protein with a C-terminal $\mathrm{His}_{6}$-tag, the synthesized cDNA was amplified by PCR using primers designed against the 5' and 3' conserved region of the cDNA, and the high fidelity Phusion DNA polymerase (Finnzyme). An additional 15 bp was included in each primer, which corresponded to upstream and downstream bases of the PIVEX $2.3 \mathrm{~d}$ vector to enable ligation-independent In-Fusion cloning (Clontech). The primers were: forward primer 5'-AGG AGA TAT ACC ATG AGC AAA CGT AAA GCC CCT-3' and reverse primer 5'ATG AGA ACC CCC CCC TTC TGA GCG ATC TTT TGG-3'. The underlined regions represent the Danio rerio pol $\beta$-specific sequence. The PCR products were separated on a $1 \%$ agarose gel and the band corresponding to the expected cDNA coding sequence was isolated. The gel-isolated DNA fragment was purified by ethanol precipitation and inserted into linearized pIVEX vector, which was digested at the multiple cloning site by NcoI and SmaI, using the In-Fusion system (Clonetech), according to the manufacturer's instruction. The integrity of the nucleotide sequence of the constructed plasmid was confirmed by DNA sequencing.

\section{Overexpression and purification of Danio rerio pol $\beta$}

Plasmid pIVEX-pol $\beta$ was used to transform E. coli KRX (Promega), BL21(DE3) (Nippon Gene), and BL21(DE3) pLysS (Novagen) cells for expression of Danio pol $\beta$. Transformed cells were plated and cultured on LB plates containing ampicillin $(100 \mu \mathrm{g} / \mathrm{ml})$ at $37^{\circ} \mathrm{C}$ overnight. Individual bacterial colonies were grown overnight in 5 $\mathrm{ml}$ of LB medium supplemented with ampicillin (100 $\mu \mathrm{g} / \mathrm{ml})$ at $30^{\circ} \mathrm{C}$ to a cell density of $0.6 \mathrm{OD}_{600}$. During

Table 1 Kinetics of Danio pol $\beta$ in the presence of $\mathrm{Mg}^{2+}$ or $\mathrm{Mn}^{2+}$

\begin{tabular}{ccccc}
\hline Metal ion & Substrate & $K_{\mathrm{m}}[\mu \mathrm{M}]$ & $\boldsymbol{k}_{\text {cat }}\left[\mathrm{min}^{-1}\right] \boldsymbol{k}_{\text {cat }} / K_{\mathrm{m}} \times 10^{3}\left[\mu \mathrm{M}^{-1} \mathrm{~min}^{-1}\right]$ \\
\hline $\mathrm{Mg}^{2+}$ & $\mathrm{dTTP}$ & 14.69 & 0.74 & 0.05 \\
$\mathrm{Mn}^{2+}$ & $\mathrm{dTTP}$ & 1.32 & 0.58 & 0.43 \\
\hline
\end{tabular}


this pre-culturing, the $\mathrm{OD}_{600}$ value was recorded at 30 min intervals with an optical density monitor (Taitech). The next day, a fresh $1 \%$ inoculum was added into 200 $\mathrm{ml}$ of LB medium containing $100 \mu \mathrm{g} / \mathrm{ml}$ ampicillin at $25^{\circ} \mathrm{C}$ until an $\mathrm{OD}_{600}$ of approximately 0.8 was reached. At this point, $1 \%$ rhamnose (Promega) was added to the growth culture of KRX E. coli containing pIVEX-pol $\beta$ for induction of recombinant protein expression. Cells were harvested by centrifugation at $3300 \times g$ for $10 \mathrm{~min}$, gently suspended in $20 \mathrm{ml}$ lysis buffer $(300 \mathrm{mM} \mathrm{KCl}, 50$ $\mathrm{mM} \mathrm{KH} \mathrm{HO}_{4}, 5 \mathrm{mM}$ imidazole, $\mathrm{pH}$ 8.0) and sonicated on ice (20 times, $30 \mathrm{~s})$. After centrifugation at $5800 \times g$ for $30 \mathrm{~min}$, the soluble fraction was filtered through a $0.45 \mu \mathrm{m}$ pore-membrane (Millipore). Recombinant protein was purified and its buffer was exchanged using the Profinia protein purification system (Bio-Rad). Recombinant protein in the soluble fraction was applied to an $\mathrm{Ni}^{2+}$-NTA affinity chromatography column with $1 \mathrm{ml}$ column volume (Bio-Rad) previously equilibrated with wash buffer 1 (50 $\mathrm{mM}$ potassium phosphate, $\mathrm{pH} 8.0$, $300 \mathrm{mM} \mathrm{KCl}, 5 \mathrm{mM}$ imidazole). The column was allowed to equilibrate with the lysate and the unbound protein was eluted from the column with six column volumes of wash buffer 1 , followed by elution of weakly bound protein with six column volumes of wash buffer $2(50 \mathrm{mM}$ potassium phosphate, $\mathrm{pH} 8.0,300 \mathrm{mM} \mathrm{KCl}$, $10 \mathrm{mM}$ imidazole). Tightly bound fusion protein was eluted with three column volumes of elution buffer (50 $\mathrm{mM}$ potassium phosphate, $\mathrm{pH} 8.0,300 \mathrm{mM} \mathrm{KCl}, 250$ $\mathrm{mM}$ imidazole). The eluted protein was applied to a gel chromatography column (Bio-Rad) previously equilibrated phosphate buffer saline (137 mM NaCl, $2.7 \mathrm{mM}$ $\mathrm{KCl}, 4.3 \mathrm{mM} \mathrm{Na}_{2} \mathrm{HPO}_{4}, 8.1 \mathrm{mM} \mathrm{KH_{2 }} \mathrm{PO}_{4}, \mathrm{pH}$ 7.4) for desalting of the elution buffer. The purified protein was concentrated at $\sim 2 \mathrm{mg} / \mathrm{ml}$ by ultrafiltration using an Amicon Ultra filter (MWCO: $10 \mathrm{~K}$, Millipore) by centrifugation for $30 \mathrm{~min}$ at $8000 \times g$ at $4^{\circ} \mathrm{C}$. The same volume of glycerol was added to the concentrated sample solution to make an approximately $1 \mathrm{mg} / \mathrm{ml}$ stock sample solution in $50 \%(\mathrm{v} / \mathrm{v})$ glycerol for storage at $-80^{\circ}$ $\mathrm{C}$. The production yield of the recombinant protein was evaluated by determining the amount of the purified protein against the volume of the culture. The amount of the purified protein was determined using the Bradford method. One milliliter of 1:5 diluted dye solution (Bio-Rad) was added to $100 \mu \mathrm{l}$ of the purified protein and standards protein of bovine serum albumin. After incubation for $5 \mathrm{~min}$ at room temperature, an absorbance at $595 \mathrm{~nm}$ was measured. The amount of purified protein was determined by measuring the absorbance and referring to a calibration curve generated using the standard protein. Recombinant rat pol $\beta$ was expressed and purified from E. coli as described by Date et al. [28]. Cell-free expression of Danio pol $\beta$ and rat pol $\beta$ was performed in RTS100 E. coli HY (5 Prime), as described in the instruction manual. Recombinant protein production was carried out in a $50 \mu \mathrm{l}$ volume with $0.5 \mu$ g of pIVEX-pol $\beta$ plasmid for 6 hours at $30^{\circ} \mathrm{C}$. The expressed proteins from both in vivo and in vitro extracts were examined by SDS-polyacrylamide gel electrophoresis and subsequently detected by Coomassie brilliant blue staining and western blotting.

\section{DNA polymerization assay}

The template and digoxigenin (DIG)-labeled primer used in the activity assay were purchased from SigmaAldrich. The primers were labeled with DIG at the 5' end for subsequent detection in Southern blotting. The DIG-primer, 5'-GGA GGA TGG CAG CGT GAG GG3', annealed to the templates (5'-AAA AAC CCT CAC GCT GCC ATC CTC C-3') at a 1:1.2 molar ratio when heated at $95^{\circ} \mathrm{C}$ for $5 \mathrm{~min}$ and then at $65^{\circ} \mathrm{C}$ for $20 \mathrm{~min}$, followed by immediate cooling on ice. The prepared primer-template complex $(5 \mu \mathrm{M})$ was stored on ice until required.

Reactions for determining Danio pol $\beta$ activity were performed in a $10 \mu \mathrm{l}$ reaction mixture, containing 50 $\mathrm{mM}$ Tris- $\mathrm{HCl}$ (pH 8.8), $1 \mathrm{mM}$ dithiothreitol (DTT), 100 $\mu \mathrm{g} / \mathrm{ml}$ bovine serum albumin (BSA), $100 \mathrm{mM} \mathrm{KCl}, 1$ $\mathrm{mM} \mathrm{MgCl}, 0.5 \mu \mathrm{M}$ primer-template, $10 \mu \mathrm{M}$ dTTP, and $0.1 \mathrm{mg} / \mathrm{ml}$ Danio pol $\beta$. The reaction mixtures were incubated at $30^{\circ} \mathrm{C}$ for $5 \mathrm{~min}$ and the reaction was terminated by the addition of $7 \mu \mathrm{l}$ stop solution ( $95 \%$ formamide, $20 \mathrm{mM}$ ethylenediaminetetraacetic acid, 0.05\% bromophenol blue, and $0.05 \%$ xylene cyanol FF).

To compare the activity of Danio pol $\beta$ with rat $\operatorname{pol} \beta$, the reaction of rat pol $\beta$ activity was performed in a 10 $\mu \mathrm{l}$ reaction containing $50 \mathrm{mM}$ Tris- $\mathrm{HCl}(\mathrm{pH} 8.0), 2 \mathrm{mM}$ DTT, $150 \mathrm{mM} \mathrm{KCl}, 5 \mathrm{mM} \mathrm{MgCl} 2,0.5 \mu \mathrm{M}$ primer-template, $10 \mu \mathrm{M}$ dTTP and $0.1 \mathrm{mg} / \mathrm{ml}$ rat pol $\beta$. The reaction mixture was incubated at $37^{\circ} \mathrm{C}$ for $5 \mathrm{~min}$, and $7 \mu \mathrm{l}$ of stop solution was added to quench the reaction.

Products were analyzed by sequencing gel electrophoresis. Each quenched reaction mixture was incubated at $95^{\circ} \mathrm{C}$ for $5 \mathrm{~min}$, and then analyzed by electrophoresis under denaturing conditions [12\% acrylamide, $7 \mathrm{M}$ urea, and sodium taurine (ST) running buffer] for $2.5 \mathrm{~h}$ with the power supply fixed at $40 \mathrm{~W}$ during electrophoresis $[29,30]$. Following electrophoresis, the gel was contactblotted onto a positively charged nylon membrane (Roche) for $45 \mathrm{~min}$ and then cross-linked $\left(200 \mathrm{~mJ} / \mathrm{cm}^{2}\right)$ using light at a wavelength of $254 \mathrm{~nm}$. The membrane was incubated in a blocking buffer [0.1 $\mathrm{M}$ maleic acid, $0.15 \mathrm{M} \mathrm{NaCl} \mathrm{pH} \mathrm{7.5,1 \% (w/v)} \mathrm{blocking} \mathrm{reagent;} \mathrm{Roche]}$ on a rocking platform for $30 \mathrm{~min}$. The blocked membrane was incubated with anti-DIG-AP Fab fragments (Roche) diluted 1:50,000 in blocking buffer for $60 \mathrm{~min}$. The membrane was washed three times with wash 
buffer (0.1 M maleic acid, $0.15 \mathrm{M} \mathrm{NaCl}, \mathrm{pH} 7.5,0.3 \%$ Tween 20) for 20 min each. The membrane was then incubated in detection buffer $(0.1 \mathrm{M}$ Tris- $\mathrm{HCl} \mathrm{pH} 9.5$, $0.1 \mathrm{M} \mathrm{NaCl}$ ) on a rocking platform for $20 \mathrm{~min}$. Finally, the membrane was incubated with CDP Star (Roche) at a 1:500 dilution in detection buffer for $10 \mathrm{~min}$. The membrane was exposed to X-ray film (Fuji Film) in the dark and the film developed in a medical film processor (FPM100; Fuji Film).

\section{Kinetic assays of Danio rerio pol $\beta$}

Kinetic Incorporation of dTTP (Takara) by pol $\beta$ of Danio rerio or rat was performed in the same reaction buffer and temperature $\left(30^{\circ} \mathrm{C}\right)$ that was used for the respective DNA polymerization assay in a total volume of $10 \mu \mathrm{l}$ containing $0.5 \mu \mathrm{M}$ of the primer-template complex. The concentrations of dTTP use were 3.75, 5, 7.5, 10, 15, and $20 \mu \mathrm{M}$. The reaction mixture was incubated for 5 min. The kinetics of dTTP incorporation were determined using sequencing gel assay $[31,32]$. The velocity of the reaction, $v$ (amount of extension products per minute), was calculated from the ratio of the amount of extended products to the total amount of primer in each lane. The $K_{\mathrm{m}}$ and the maximum velocity $\left(V_{\max }\right)$ for dTTP incorporation were calculated using least-square fitting from a Hanes-Woolf plot of [dTTP] $/ v$ against [dTTP]. The $K_{\text {cat }}$ was calculated by dividing $V_{\max }$ by the enzyme concentration. The amount of extended product was estimated from the intensity of each band following subsequent sequencing electrophoresis analysis with GelPro Analyzer software (Media Cybernetics).

\section{Acknowledgements \\ This work was supported by a grant from the Industrial Technology Research Program from the New Energy and Industrial Technology Development Organization (NEDO), Japan.}

\section{Author details}

${ }^{1}$ Health Research Institute, National Institute of Advanced Industrial Science and Technology (AIST), Takamatsu, Kagawa 761-0395, Japan. ${ }^{2}$ Faculty of Pharmaceutical Sciences, University of Tokushima, Sho-machi, Tokushima 770-8505, Japan.

\section{Authors' contributions}

$\mathrm{TI}$ carried out all experiments except the DNA sequencing and the cell-free expression and drafted the manuscript. NY discussed on the molecular cloning studies and the results obtained. Ml discussed on the results obtained and helped to draft the manuscript. KH conceived the study, and participated in its design and coordination and helped to draft the manuscript. All authors read and approved the final manuscript.

\section{Competing interests}

The authors declare that they have no competing interests.

Received: 11 August 2011 Accepted: 21 October 2011 Published: 21 October 2011

\footnotetext{
References

1. Wang TSF: Eukaryotic DNA polymerases. Annu Rev Biochem 1991, 60:513-552.
}

2. Budd ME, Campbell JL: The roles of the eukaryotic DNA polymerases in DNA repair synthesis. Mutat Res 1997, 384:157-167.

3. Cleaver JE, Karpus K, Kashani-Sabet M, Limoli CL: Nucleotide excision repair 'a legacy of creativity'. Mutat Res 2001, 485:23-26.

4. Hubscher U, Nasheuer HP, Syvaoja JE: Eukaryotic DNA polymerases, a growing family. Trends Biochem Sci 2000, 25:143-147.

5. Burgers PM, Koonin EV, Bruford E, Blanco L, Burtis LC, Christman MF Copeland WC, Friedberg EC, Hanaoka F, Hinkle DC, Lawrence CW, Nakanishi M, Ohmori H, Prakash L, Prakash S, Reynaud C-A, Sugino A, Todo T, Wang Z, Weill J-C, Woodgate R: Eukaryotic DNA polymerases: proposal for a revised nomenclature. J Biol Chem 2001, 276:43487-43490.

6. Fry M, Loeb LA: Animal Cell DNA Polymerases Boca Raton, FL: CRC Press; 1986.

7. Zollner H: Handbook of enzyme inhibitors, 3 rd rev Wiley VCH; 1999.

8. Kornberg A, Baker TA: DNA replication. 2 edition. Sausalito, CA: University Science Books; 1992.

9. Matsumoto $Y$, Kim K: Excision of deoxyribose phosphate residues by DNA polymerase beta during DNA repair. Science 1995, 269:699-702.

10. Sawaya MR, Pelletier H, Kumar A, Wilson SH, Kraut JA: Crystal structure of the rat DNA polymerase beta: evidence a common polymerase mechanism. Science 1994, 264:1930-1935.

11. Yamaguchi T, Nishimura S, Takahashi K, Yoshikuni M, Masaki J, Hirai T, Saneyoshi M: DNA polymerase $\beta$ s from liver and testes of Cherry Salmon, Oncorhynchus masou: Purification and characterization of DNA polymerase $\beta$ s with acidic isoelectric points. J Biochem 1996, 119:186-192.

12. Oehlers LP, Heater SJ, Rains JD, Wells MC, David WM, Walter RB: Gene structure, purification and characterization of DNA polymerase $\beta$ from Xiphophorus maculatus. Comp Biochem Phys C 2004, 138:311-324.

13. Fishman MC: Genomics. Zebrafish-the canonical vertebrate. Science 2001, 294:1290-1291.

14. Dooley K, Zon Ll: Zebrafish: a model system for the study of human disease. Curr Opin Genet Dev 2000, 10:252-256.

15. Berghmans S, Murphey RD, Wienholds E, Neuberg D, Kutok JL, Fletcher CDM, Morris JP, Liu TX, Schulte-Merker S, Kanki JP, Plasterk R, Zon LI, Look AT: tp53 mutant zebrafish develop malignant peripheral nerve sheath tumors. Proc Natl Acad Sci USA 2005, 102:407-412.

16. Xu X, Zhang L, Weng S, Huang Z, Lu J, Lan D, Zhong X, Yu X, Xu A, He J: A zebrafish (Danio rerio) model of infectious spleen and kidney necrosis virus (ISKNV) infection. Virology 2008, 376:1-12.

17. Augustine-Rauch K, Zhang CX, Panzica-Kelly JM: In vitro developmental toxicology assays: a review of the state of the science of rodent and zebrafish whole embryo culture and embryonic stem cell assays. Birth Defects Res C Embryo Today 2010, 90:87-98.

18. Zon LI, Peterson RT: In vivo drug discovery in the zebrafish. Nat Rev Drug Discov 2005, 4:35-44.

19. Roge J, Betton J-M: Use of pIVEX plasmids for protein overproduction in Escherichia coli. Microb Cell Fact 2005, 4:18.

20. Ghosh S, Thakur MK: Overproduction of mouse estrogen receptor alphaligand binding domain decreases bacterial growth. Mol Biol Rep 2008, 35:589-594.

21. Arndt JW, Gong W, Zhong X, Showalter AK, Liu J, Dunlap CA, Lin Z, Paxson C, Tsai M-D, Chan MK: Insight into the catalytic Mechanism of DNA polymerase $\beta$ : Structures of intermediate complexes. Biochemistry 2001, 40:5368-5375.

22. Hartnett JH, Gracyalny MSJ, Slater MR: The single step (KRX) competent cells: Efficient cloning and high protein yields. Promega Notes 2006, 94:27-30.

23. Maga G, Shevelev I, Villani G, Spadari S, Hübscher : Human replication protein A can suppress the intrinsic in vitro mutator phenotype of human DNA polymerase $\lambda$. Nucleic Acids Res 2006, 34:1405-1415.

24. Eigen M: Fast elementary steps in chemical reaction mechanisms. Pure Appl Chem 1963, 6:97-115.

25. Margerum DW, Cayley GR, Weatherburn DC, Pagenkopf GK: In Coordination Chemistry. Edited by: Martell AE. Washington, DC: American Chemical Society; 1978:1-200, Vol. 2..

26. Hays H, Berdis AJ: Manganese Substantially Alters the Dynamics of Translesion DNA Synthesis. Biochemistry 2002, 41:4771-4778.

27. Pelletier H, Sawaya MR: Characterization of the Metal lon Binding HelixHairpin-Helix Motifs in Human DNA Polymerase $\beta$ by X-ray Structural Analysis. Biochemistry 1996, 35:12778-12787. 
28. Date T, Yamaguchi M, Hirose F, Nishimoto $Y$, Tanihara K, Matsukage A: Expression of active rat DNA polymerase $\beta$ in Escherichia coli. Biochemistry 1988, 27:2983-2990.

29. Hirano K, Ishido T, Ishikawa M: Rapid sequencing gel electrophoresis using glycerol-tolerant sodium taurine medium. Anal Biochem 2009, 390:100-101.

30. Hirano K, Yoshida Y, Ishido T, Wada Y, Moriya N, Yamazaki N, Mizushina Y, Baba Y, Ishikawa M: Consecutive incorporation of fluorophore-labeled nucleotides by mammalian DNA polymerase $\beta$. Anal Biochem 2010, 405:160-167

31. Boosalis MS, Petruska J, Goodman MF: DNA polymerase insertion fidelity: gel assay for site-specific kinetics. J Biol Chem 1987, 262:14689-14696.

32. Creighton S, Bloom LB, Goodman MF: Gel fidelity assay measuring nucleotide misinsertion, exonucleolytic proofreading, and lesion bypass efficiencies. In Methods in Enzymology: DNA replication. Volume 262. Edited by: Campbell JL. San Diego: Academic Press; 1995:232-256.

doi:10.1186/1475-2859-10-84

Cite this article as: Ishido et al: Characterization of DNA polymerase $\beta$ from Danio rerio by overexpression in E. coli using the in vivo/in vitro compatible pIVEX plasmid. Microbial Cell Factories 2011 10:84.

\section{Submit your next manuscript to BioMed Central} and take full advantage of:

- Convenient online submission

- Thorough peer review

- No space constraints or color figure charges

- Immediate publication on acceptance

- Inclusion in PubMed, CAS, Scopus and Google Scholar

- Research which is freely available for redistribution

Submit your manuscript at www.biomedcentral.com/submit 